\title{
TİCARİ ÖNEME SAHİP TOZ SÜT ÜRÜNLERİNIN MORFOLOJİK YAPISI VE TOZ AKIŞ ÖZELLİKLERİNİN BELİRLENMESİ
}

\author{
Meryem Göksel Saraç ${ }^{1}$, Duygu Aslan Türker ${ }^{2}$, Mahmut Doğan $^{2,3, *}$ \\ ${ }^{1}$ Cumhuriyet Üniversitesi, Yıldızeli Meslek Yüksekokulu, Gıda Teknolojisi, Sivas \\ Erciyes Üniversitesi, Mühendislik Fakültesi, Gıda Mühendisliği Bölümü, Kayseri \\ ${ }^{3}$ TAGEM Gıda Analiz Merkezi San. Tic. Ltd. Şti., Erciyes Teknopark, Kayseri
}

Geliş / Received: 20.09.2020; Kabul / Accepted: 04.12.2020; Online bask1 / Published online: 30.12.2020

Göksel Saraç, M., Aslan Türker, D., Doğan, M. (2021) Ticari öneme sahip toz süt ürünlerinin morfolojik yapısı ve toz akış özelliklerinin belirlenmesi. GIDA (2021) 46(1) 119-133 doi: 10.15237/gida.GD20108

Göksel Sarac, M., Aslan Türker, D., Doğan, M. (2021) Determination of morphological structure and powder flow characteristics of commercially important powdered milk products. GIDA (2021) 46(1) 119-133 doi: 10.15237/gida.GD20108

\section{ÖZ}

Bu çalışmada gida ürünlerinin formülasyonunda önemli yer tutan toz süt ürünlerinden kazein, laktoz, yağl1 süt tozu ve peynir tozu seçilmiş, kekleşme derecesi, toz akış hızı bağımlılık testi ve kohezyon testi ile ıslanabilirlik, çözülebilirlik, yığın ve sıkışturlmış yoğunluk ve morfolojik yapı gibi toz akış karakterizasyonu gerçekleştirilmiştir. Toz süt ürünlerinin ortalama tane boyutu ile toz özellikleri ve fizikokimyasal özellikleri belirlenmiştir. Örneklerin çözünürlük, ıslanabilirlik, yığın ve sıkıştırılmış yoğunluk ve Carr indeks değerleri, sirasıyla \%2.87-58.72, 1.15-60.00 dk, 0.49-0.60, 0.58-0.71 ve \%11.01-22.00 aralığında olduğu gözlenmiştir. Süt tozu en düşük nem ve ortalama tane boyutu ile Carr indeks değerlendirmesinde çok iyi akış gösteren örnek olarak belirlenirken çözünürlük oranı en yüksek toz ürün olmuştur. En düşük çözünürlük ve 1slanabilirlik değerleri ile tespit edilen kazein en yüksek ortalama tane boyutuna sahip ürün olarak belirlenmiştir. Örnekler içerisinde tek kekleşme görülen laktoz en uzun sürede 1slanabilen örnek olarak saptanmiştur.

Anahtar kelimeler: Süt tozu, kazein, laktoz, peynir tozu, toz akış, tanecik boyutu, fizikokimyasal özellikler

\section{DETERMINATION OF MORPHOLOGICAL STRUCTURE AND POWDER FLOW CHARACTERISTICS OF COMMERCIALLY IMPORTANT POWDERED MILK PRODUCTS}

\begin{abstract}
In this study, casein, lactose, full fat milk powder and cheese powder were selected which have a great importance in food formulations. The caking, powder flow rate dependency test as well as the wettability, solubility, bulk and tapped bulk density and morphological structure was determined. The solubility, wettability, bulk and tapped bulk density and Carr index values of the samples were in the range of $2.87-58.72 \%, 1.15-60.00 \mathrm{~min}, 0.49-0.60,0.58-0.71$ and $11.01-22.00 \%$, respectively. Whereas milk powder was identified as the sample with the lowest moisture and average particle size in the Carr index, it was determined as the product with the highest average particle size in terms of the
\end{abstract}

\footnotetext{
${ }^{*}$ Yazışmalardan sorumlu yazar / Corresponding author

田: dogan@erciyes.edu.tr (D): (+90) $3522076666 / 32751$ 国: (+90) 3524375784
}

Meryem Göksel Saraç; ORCID no: 0000-0002-8190-2406

Duygu Aslan Türker; ORCID no: 0000-0002-9579-8347

Mahmut Doğan; ORCID no: 0000-0003-1639-4641 
solubility rate. Casein determined with the lowest solubility and wettability values was found as the product with the highest average particle size. Among samples, lactose was the only sample which caking phenomenon was determined as the sample with the longest wettability.

Keywords: Milk powder, casein, lactose, cheese powder, powder flow, particle size, physicochemical properties

\section{GİRIŞ}

Süt ve süt ürünleri gida sektörü içerisinde oldukça önemli bir üretici ve tüketici kitlesine sahiptir (Özcan, 2011). Süt ve ürünleri içerisinde en dikkat çekici ürün grubunu dünyadaki üretimi ve kullanımındaki artış nedeniyle süt ve ürünlerinden üretilen tozlar oluşturmaktadır (Himmetağaoğlu vd., 2019). Diğer taraftan Ekonomik İşbirliği ve Kalkınma Teşkilatı-Gıda ve İlaç İdaresinin (OECD-FAO) 2021 yllı planlarına göre, yıllık \% 2.6 büyüme oranı ile üretimi en hızlı artması beklenen ürünlerin süt ve ürünlerinden elde edilen toz bileşenler olması, endüstriyel üretim açısından süt ve ürünlerinden elde edilen tozların önemini göstermektedir (IDF, 2012). Ayrıca kimyasal ve mikrobiyel olarak dayanıklı olmalan, kitlık vb. gibi acil durumlarda gida stoku sağlamaları, taşıma ve depolama kolaylıkları, gıda ürünleri araştırma ve geliştirme çalışmalarında ve endüstriyel üretimde katk1 maddesi olarak kullanılmaları gibi nedenlerden dolayı toz süt ve süt ürünleri gün geçtikçe daha fazla kullanım alanı bulmaktadır (Tamime, 2009). Süt ve ürünlerinden yağlı ve yağsız süt tozu, peynir altı suyu tozu, kazein, peynir tozu, laktoz, krema ve yoğurt tozu elde edilmektedir (Schuck, 2011). Elde edilen bu toz ürünler; tatlı ve pastacılık ürünleri, şekerlemeler, bebek mamaları, kek karışımları, çikolatalar, çorbalar, hazır soslar, kahve beyazlatıcıları, dondurma karışımları, çerez kaplamaları ve süt bazlı içeceklerin formülasyonlarında sıklikla kullanılmaktadır (Chudy vd., 2015).

Toz halinde endüstriyel olarak üretilen, çok sayıda ve çeşitli süt ürününün; ambalajlama, işleme ve depolama özelliklerinin belirlenebilmesi için bu ürünlerin toz akış özelliklerinin belirlenmesi önem arz etmektedir (Fitzpatrick vd., 2007). Öte yandan toz gidalarda görülen akış problemleri, gıda işletmelerindeki bunker ve silolarda üretimi yavaşlatıp enerji ve iş gücü kaybına neden olan önemli sorundur. Ayrıca, çuval ve silolarda yığın halinde depolanan toz gida ürünleri ileri derecede kekleşme meydana getirerek ve son üründe kalite kayılarına neden olmaktadır (Fitzpatrick vd., 2017).

Toz ürünlerde görülen kekleşme, düşük nem oranına sahip, serbestçe akan bir tozun önce yı̆̆ınlara, daha sonra topaklaşmış bir kattya ve nihayetinde yapışkan bir malzemeye dönüştügü, üründe işlevsellik kaybına ve düşük kaliteye neden olan istenmeyen bir oluşumdur (JoséM Aguilera vd., 1995). Toz ürün kekleşmesinin bir diğer tanımı, kolayca ve serbestçe akan bir tozun akmaya karşı dirençli topaklanmış bir yapıya dönüştüren istenmeyen tanecik agregasyonu olarak yapilabilir (Zafar vd., 2017). Süt ve ürünlerinde görülen kekleşme ise süt ürünleri endüstrisinde uzun yıllardan beri karşılaşılan önemli bir sorundur (Carpin vd., 2016). 1930'lu yıllarda Troy vd. (1930) süt tozunda görülen kekleşme problemi için üç basmaktan oluşan basit ve genel bir mekanizma önermiştir. Bunlar; (i) süt tozu içerisinde bulunan laktoz tarafından nemin tutulması; (ii) parçacıkların bir araya gelerek zamanla topaklaşması, (iii) kristalizasyon ve sonrasında laktozun bir kısmının katılaşmasıdır. Toz süt ürünlerinde meydana gelen kekleşme mekanizmasını anlayabilmek için bu üç mekanizmanın iyi anlaşılması gerekmektedir. Bu maddelerden ilki amorf malzemenin kristalleşmesi, ikincisi ise kristal parçacıların nem tutması ile ilgilidir. Ürünlerin ve ortamın nem içeriği her iki mekanizma için de oldukça önemli bir parametredir. Üçüncü madde ise ilk iki maddeye kıyasla nem içeriği ile ilgili olmayıp parçaciklar arasındaki kuvvetlerin dengesinden etkilenmektedir (Carpin vd., 2016). Gida ürünlerinin toz akışını etkileyen diğer bir faktör ise tozların tanecik büyüklügüüdür (O'Donoghue vd., 2019). Mathlouthi vd. (2003)'nın sükrozun nem sorpsiyonu ve kekleşme özellikleri üzerine tanecik büyüklüğünün etkisini araştırdıkları çalışmalarında sükroz içerisindeki küçük boyuttaki tanecik miktarı $(<250 \mu \mathrm{m})$ ne kadar yüksekse, sükrozun o kadar fazla nem absorbe ettiğini belirtmiştir. Ayrıca, toz ürünlerin kohezifliğinin azalan tanecik 
büyüklüğü ile arttğı rapor edilmiştir. $\mathrm{Bu}$ çalışmanın paralelinde Provent vd. (1993)'de toz ürünlerin kekleşmesinin ana nedeninin tanecik boyutu olduğunu belirtmişlerdir. Araştırmacılar, büyük ve küçük tanecik boyutuna sahip toz ürünleri farklı oranlarda karıştırarak, kekleşmenin hem toz ürünün toplam yüzey alanından hem de tanecik boyutu dağılımından etkilendiğini kanıtlamışlardır.

$\mathrm{Bu}$ çalş̧mada da birçok gıda ürünün formülasyonunda siklikla kullanilan laktoz, süt tozu, peynir tozu ve kazeinin kekleşme derecesi, toz akış hızı bağımlılık testi ve kohezyon testi gibi toz akış özellikleri ile tanecik büyüklüğü arasındaki ilişki belirlenmiştir. Ayrıca bu ürünlerin renk, nem ve su aktivitesi gibi fizikokimyasal özellikleri belirlenerek akış davranışı özelliklerine etkisinin araştrrilması amaçlanmıştır. Elde edilen sonuçlar 1şı̆̆ında özellikle depolama ve ambalajlamada önemli problemlere neden olan kekleşme ile ürünlerin fizikokimyasal özelliklerinin ilişkisi arasındaki bağlantı belirlenmeye çalışlmıştur. Mevcut literatürde toz süt ürünlerinin akış davranışlarını inceleyen ve toz süt ürünlerinin toz akış özellikleri ile fizikokimyasal özelliklerinin birlikte incelendiği herhangi bir çalışmaya ulaşılamadığ1 için elde edilen çıtılların hem literatüre hem de endüstriyel uygulamalara katkı sağlayacağı düşünülmektedir.

\section{MATERYAL VE YÖNTEM \\ Materyal}

Çalışma kapsamında kullanılan toz süt ürünlerinden kazein Abcr A.Ş. (Almanya), yağlı süt tozu (ürün bileşimi $\% 26.0$ yağ, kurumaddede \%35.0 protein, \%37.5 laktoz) Enka A.Ş. (Türkiye), laktoz Laktoprot A.Ş. (Almanya) ve peynir tozu (lor peynirinden pnomatik kurutucu ile üretilmiştir) (ürün bileşimi \%39.0 yağ, \%36.1 protein, \%9.5 laktoz) Kurutucum G1da (Türkiye)'den temin edilmiştir (Şekil 1).

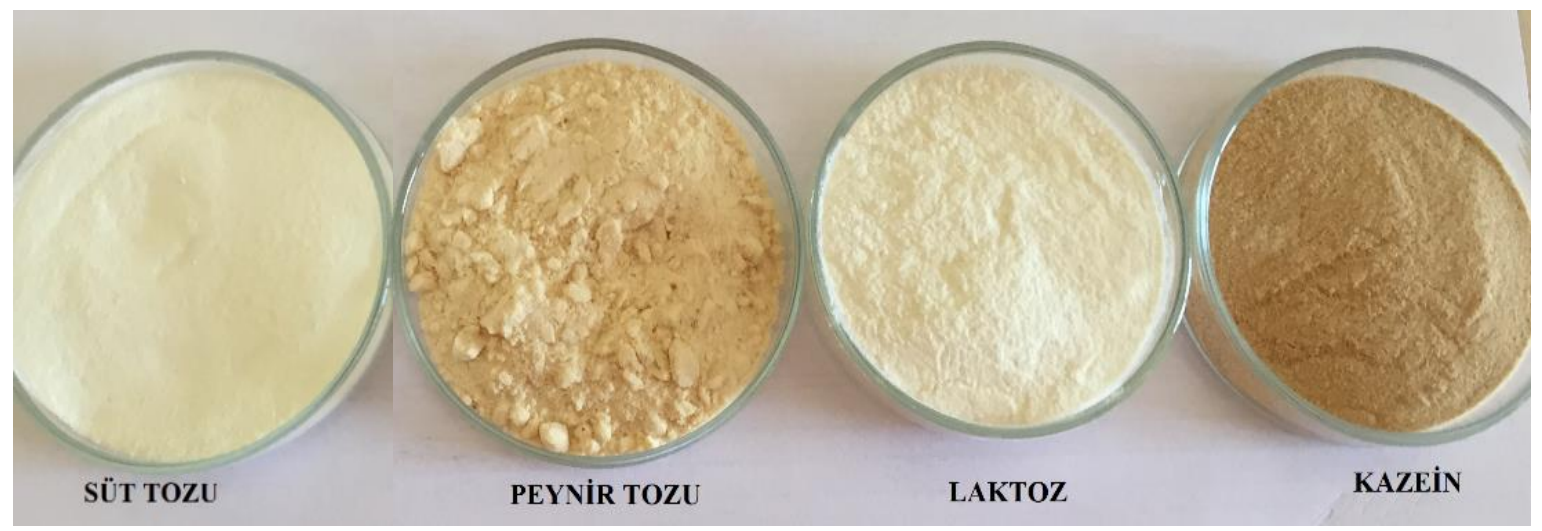

Şekil 1. Çalışmada kullanılan toz süt ürünleri

Figure 1. Powdered dairy products used in the study

\section{Fizikokimyasal analizler}

Nem miktarı, toz süt ürünlerinin $105^{\circ} \mathrm{C}^{\prime}$ de sabit tartıma gelene kadar kurutulmasiyla hesaplanmiştır (AOAC, 2000). Toz süt ürünlerinin su aktivitesi değerleri su aktivitesi tayin cihazı (Aqua Lab 2.0, ABD) kullanilarak ölçülmüştür. Renk değerleri ise $L^{*}$ (açıklık/koyuluk), $a^{*}$ (kırmızılık/yeşillik) ve $b^{*}$ (sarllık/mavilik) parametreleri üzerinden renk tayin cihazı (Konica-Minolta, CR400, Japonya) kullanılarak belirlenmiştir.

\section{Toz özellik analizleri}

Toz süt ürünlerinin çözünürlük analizi yöntemde bazı modifikasyonlar yapılarak gerçekleştirilmiştir. 5 gr örnek saf su ile kanşstırlmış ve homojen karısıım elde edildikten sonra 5000 RPM'de $5 \mathrm{dk}$ santrifüjlenmiştir. Üstte kalan karışımdan $20 \mathrm{~mL}$ alınarak $80{ }^{\circ} \mathrm{C}$ 'de sabit tartıma gelene kadar kurutularak hesaplamalar yapılmıştır (Takahashi vd., 1988).

Islanabilirlik analizi için Freudig vd. (1999) yöntemi modifiye edilerek 0.5 gr örnek tartılmış 
ve $50 \mathrm{~mL}$ saf su içerisine atılmıs ve tüm taneciklerin tamamen kaybolması için gerekli süre kaydedilmiştir.

Yığın yoğunluk $\left(\rho_{\text {y̆ğn }} \mathrm{g} / \mathrm{cm}^{3}\right)$ analizi için toz süt ürünleri $50 \mathrm{~mL}$ 'lik mezürlere herhangi bir basınç uygulamadan tartılmış ve ağırlıkları kaydedilmiştir. Sikıştırilmış yoğunluk $\left(\rho_{\text {skkıștrulmıs }} \mathrm{g} / \mathrm{cm}^{3}\right)$ analizi için ise aynı örnekler 180 saniye boyunca düzgün bir zemine vurulmuş ve süre sonunda son hacim kaydedilmiştir. Yığın ve sıkıştırılmış yoğunluk analizleri kütle/hacim oran1 hesabiyla belirlenmiştir (Du vd., 2014). Örneklerin car indeks değerleri aşağıda verilen formül ile hesaplanmıştır (Turchiuli vd., 2005).

Carr İndeks Değeri $=\frac{\text { S1kıştırılmış Yoğunluk-Yığın Yoğunluğu }}{\text { Sıkıştırılmış Yoğunluk }} \times 100$

\section{Toz akış özellikleri}

Toz süt ürünlerinin toz akış özellikleri kohezyon testi, toz akış hızı bağımlılık testi (PFSD testi) ve kekleşme testi (caking test) başlıklarında Stable Micro System (TA-XT2 Plus, İngiltere) tekstür cihazı ile özel toz akış ölçüm bıçağı ile gerçekleştirilmiştir. Toz süt ürünlerinin kohezyon testi probun $50 \mathrm{~mm} \cdot \mathrm{s}^{-1}$ hizda yukarı doğru ç1kmasıyla belirlenirken, kohezyon endeks oranı kohezyon katsayısı/örnek ağırlığ1 ile hesaplanmiştır (Landillon vd., 2008). PFSD testi ise $10,20,50,100 \mathrm{~mm} \cdot \mathrm{s}^{-1}$ artan hizlarda belirlenen kuvvet/mesafe eğrisinin altundaki pozitif alan baz alınarak belirlenmiştir (de Freitas Eduardo vd., 2007). Kekleşme ve kekleşme kuvveti değerlendirmesi ise prob sıkıştırmaları sırasında ölçülen kolon yüksekliği ile hesaplanmıştır (Benkovic vd., 2009). Toz akış analizi sonucunda elde edilen veriler Test Texture Exponent 32 yazılımı kullanılarak hesaplanmıştır.

\section{Elek analizi}

Toz süt ürünlerinin tanecik boyutunun belirlenmesi için elek analizi titreşimli elek sallayıc1 cihaz1 ile (Retsch AS 200, Almanya) kullanilarak $0.053-0.212 \mu \mathrm{m}$ aralı̆̆ındaki çaplara sahip 8 adet elek ile belirlenmiştir. 50 gr örnek tartılmış ve 10 $\mathrm{dk}$ boyunca eleklerden geçmesi için sarsılmıştur. Analiz sonucunda her bir örnek için ortalama tane boyutu değerleri $\left(\mathrm{d}_{50}\right)$ hesaplanmıştur (Oskaybaş, 2016).

\section{Morfolojik yapı analizi}

Toz süt ürünlerinin morfolojik yapıları Taramalı Elektron Mikroskobu (SEM) (Tescan Mira3, Çek Cumhuriyeti) ile belirlenmiştir.

\section{İstatistiksel analiz}

Toz süt ürünlerinde yapılan analizlerin değerlendirilmesi için tek yönlü varyans analizi (ANOVA), Minitab (Windows Sürüm 18 için MINITAB) programı ile gerçekleştirilmiştir. Ayrica Tukey testi, numuneler arasındaki fark1 yorumlamak ve ortalamaları karşılaştırmak için yapilmıştır $(P<0.05)$.

\section{BULGULAR VE TARTIŞMA \\ Fizikokimyasal özellikler}

Toz süt ürünlerinin nem miktarları, su aktivitesi ve renk değerleri Çizelge 1'de gösterilmektedir. Süt ve ürünlerinden elde edilen tozların nem değerleri $\% 4.55$ ile 7.82 arasında belirlenmiştir. Süt tozu ile laktoz en düşük nem değerlerine sahipken aralarında istatistiksel açıdan bir fark bulunmamıştır $(P>0.05)$. Öte yandan en yüksek nem oranı peynir tozunda tespit edilmiş ve kazein ile nem miktarı açısından aralarında istatistiki açıdan önemli bir fark bulunamamıştrr $(P>0.05)$. Nem miktarı toz ürünlerde toz akış özelliklerini etkiler ayrica depolama sürecinde formülasyonlarına katıldıkları ürünün yapısının bozulmaması açısından da önemlidir. Diğer taraftan özellikle süt tozlarında nem miktarının $\% 5$ barajını geçmemesi istenmektedir. Aksi durumda Maillard reaksiyonları oluşmakta ve laktoz kristalizasyonu enzimatik reaksiyonlar1 sayesinde ortaya çımaktadır (Carić, 1994). a analizi sonucunda; peynir tozunun 0.25 değeri ile en yüksek su aktivitesine sahip toz ürün olduğu belirlenmiştir. Süt tozu ve laktoz nem miktarında olduğu gibi en düşük su aktivitesi değerine sahip ürünler olarak tespit edilmiştir. Toz süt ürünlerinin renk değerlendirilmesinde kullanılan $L^{*}, a^{*}$ ve $b^{*}$ parametrelerinin tamaminda örnekler arasında fark istatistiksel açıdan önemli olarak belirlenmiştir $(P<0.05) . \quad L^{*}, a^{*}$ ve $b^{*}$ değerleri sirasiyla 74.01-97.63, (-)1.75-5.57 ve 14.27-24.22 aralığında belirlenmiştir. $L^{*}$ değerinden en yüksek süt tozu, en düşük kazein belirlenirken; $a^{*}$ ve $b^{*}$ değerlendirmelerinde en düşük süt tozu, en yüksek kazein olarak tespit edilmiştir. 
Çizelge 1. Toz süt ürünlerinin fizikokimyasal özellikleri

Table 1. Physicochemical properties of powdered dairy products

\begin{tabular}{|c|c|c|c|c|c|}
\hline \multirow{2}{*}{$\begin{array}{l}\text { Örnekler } \\
\text { Samples }\end{array}$} & \multirow{2}{*}{$\begin{array}{c}\text { Nem }(\%) \\
\text { Moisture (\%) }\end{array}$} & \multirow{2}{*}{$\begin{array}{l}a_{\mathrm{w}} \\
a_{w}\end{array}$} & \multicolumn{3}{|c|}{$\begin{array}{c}\text { Renk Değerleri } \\
\text { Color V alues }\end{array}$} \\
\hline & & & $L^{*}$ & $a^{*}$ & $b^{*}$ \\
\hline $\begin{array}{l}\text { Süt Tozu } \\
\text { Milk Powder }\end{array}$ & $4.81 \pm 0.11^{b}$ & $0.17 \pm 0.00^{c}$ & $97.63 \pm 0.11^{\mathrm{a}}$ & $-1.75 \pm 0.02^{\mathrm{d}}$ & $14.27 \pm 0.03^{\mathrm{d}}$ \\
\hline $\begin{array}{l}\text { Kazein } \\
\text { Casein }\end{array}$ & $6.88 \pm 0.08^{a}$ & $0.19 \pm 0.00^{\mathrm{b}}$ & $74.01 \pm 0.01^{\mathrm{d}}$ & $5.57 \pm 0.11^{a}$ & $24.22 \pm 0.02^{\mathrm{a}}$ \\
\hline $\begin{array}{l}\text { Peynir Tozu } \\
\text { Cheese Powder }\end{array}$ & $7.82 \pm 0.26^{a}$ & $0.25 \pm 0.01^{a}$ & $88.01 \pm 0.01^{c}$ & $3.68 \pm 0.01^{b}$ & $21.93 \pm 0.01^{b}$ \\
\hline $\begin{array}{l}\text { Laktoz } \\
\text { Lactose }\end{array}$ & $4.55 \pm 0.32^{\mathrm{b}}$ & $0.17 \pm 0.00^{c}$ & $94.41 \pm 0.01 \mathrm{~b}$ & $-0.53 \pm 0.01^{c}$ & $15.78 \pm 0.02^{c}$ \\
\hline
\end{tabular}

Aynı sütundaki farklı harfler örnekler arası farkın istatistiksel olarak önemli olduğunu gösterir. ortalama \pm standart sapma

Different letters on the same column indicate that the difference between the samples is statistically significant. mean deviation

\section{Toz özellikler}

Toz süt örneklerinin çözünürlük, 1slanabilirlik, yığın ve sıkıştırılmış yoğunluk ve Carr indeks gibi karakteristik özellikleri; formülasyonuna katılacağ1 ürünü, hazırlama şeklini ve depolama koşullarını belirleme nedeniyle önemlidir. Toz özelliklerinin belirlendiği analiz sonuçları Çizelge 2'de verilmiştir. Toz ürünlerin endüstriyel kullanımları göz önüne alındığında sslanma, dispersiyon ve çözünme aşamalarını içeren rehidrasyon özellikleri önem kazanmaktadır (Freudig vd., 1999; Schubert, 1993). Ayrica siv1 ortamlarda karıştırma ve çalkalama gibi mekanik etkilerin en az oranda kullanılması ile tam çözünen ve topaklaşma göstermeyen tozlara instant denilirken (Forny vd., 2011) diğer taraftan hizlı ve kolay bir şekilde sslanabilen tozlara da instant denilmektedir ( Schuck vd., 2012). Gıda tozlarının çözünmeleri fiziksel özellikleri ve içerdikleri yağ miktarına göre değişiklik göstermektedir ve bu özellikler nedeniyle toz ürünlerin sıvı içerisinde topaklanma sorunu görülebilmektedir (Börjesson vd., 2013). Örneklerin çözünürlük değerleri birbirinden farklı olarak hesaplanmıştr. Özellikle kazein en düşük çözünürlük oranı ile $(\% 2.87)$ diğer toz ürünlerinden oldukça farklı olarak belirlenmiştir. Öte yandan süt tozu \%58.72 çözünürlük oranı ile toz süt ürünleri içerisinde en yüksek çözünürlük özelliğine sahip ürün olarak tespit edilmiştir. Islanabilirlik, yığın halindeki bir tozun, kılcal kuvvetlerin etkisi altında bir siviyı emebilme yeteneğinin bir ölçüsüdür (Kim vd., 2002). Toz ürünlerin yüzey bileşiminin 1slanabilirlik değerlerinde önemli bir etkiye sahip olduğu bilinmektedir. Genel olarak, hidrofobik bileşenler (ör. yağ) "zayıf" 1slanabilme özelliği gösterirken, yüzeyinde higroskopik bileşenlerin (ör. laktoz) bulunduğu toz ürünler "iyi" 1slanabilme değerlerine sahip olurlar (Fäldt vd., 1996). Bu çalışma kapsamında 1slanabilirlik özellikleri değerlendirilen toz süt ürünleri değerlendirmesinde kazeinin 1slanabilirlik değeri $1.15 \mathrm{dk}$; peynir tozunun $2.10 \mathrm{dk}$; süt tozunun 1.50 $\mathrm{dk}$ ve laktozun ise $60 \mathrm{dk}$ lik sslanabilirlik değerine sahip ürünler olduğu saptanmıştır. Kim vd. (2002)'nin toz süt ürünlerinin yüzeyinde bulunan yağın örneklerin 1slanabilirlik özelliklerine etkisini araştırdıkları çalışmalarında süt tozunun sslanabilirlik değerinin yüzeyde bulunan yă̆ uzaklaştırlmadan önce $10 \mathrm{dk}$, yüzeydeki yăg uzaklaşturldıktan sonra ise $12 \mathrm{dk}$ olarak bulmuşlardır. Elde edilen bu sonuç araştırmacılar tarafindan beklenmeyen bir durum olarak yorumlanmıştrr. Çünkü yüzeyden uzaklaştırılan yağın süt tozu örneklerinin 1slanabilirlik değerini düşüreceği öngörülmüş fakat tam ters bir sonuçla karşılaşılmıştır. Elde edilen bu sonucun bir nedeni yağ ekstraksiyonu yoluyla daha fazla protein tabakasının açığa çıkması; bir diğer olası açıklaması ise yağ ekstraksiyonu esnasında yüzeyin daha higroskopik olacak şekilde değişmiş olabileceği şeklinde ifade edilmiştir. Toz 
ürünlerin 1slanabilirliği tozların yüzey özellikleri, karıştırma, sıcaklık, tanecik büyüklügü, amfipatik maddelerin varlı̆̆ına, gözenek yapısına bağlı olarak değişiklik göstermektedir (Jeantet vd., 2010; Sharma vd., 2012). Özetle, özellikle instant toz gida ürünlerinin hazırlanmasında kullanilan toz süt ürünlerinin 1slanabilirlik değerlerinin daha düşük olması ürün kalitesi açısından önemli bir parametre olarak değerlendirilebilir ve 1slanabilirlik değeri toz ürünlerin yüzeyinde bulunan hidrofobik bileşiklerin uzaklaştırilması ile arturlabilmektedir.

Çizelge 2. Toz süt ürünlerinin toz özellikleri

Table 2. Powder properties of powdered dairy products

\begin{tabular}{|c|c|c|c|c|c|}
\hline $\begin{array}{l}\text { Örnekler } \\
\text { Samples }\end{array}$ & $\begin{array}{c}\text { Çözünürlük } \\
(\%) \\
\text { Solubility (\%) }\end{array}$ & $\begin{array}{l}\text { Islanabilirlik } \\
\text { (dk) } \\
\text { Wettability } \\
\text { (min) }\end{array}$ & $\begin{array}{c}\text { Ylŭın } \\
\text { yoğunluk } \\
\left(\mathrm{g} / \mathrm{cm}^{3}\right) \\
\text { Bulk Density } \\
\left(\mathrm{g} / \mathrm{cm}^{3}\right)\end{array}$ & $\begin{array}{l}\text { S1kiştırılmış } \\
\text { yoğunluk } \\
\left(\mathrm{g} / \mathrm{cm}^{3}\right) \\
\text { Tapped Density } \\
\left(\mathrm{g} / \mathrm{cm}^{3}\right)\end{array}$ & $\begin{array}{c}\text { Carr Indeks } \\
(\%) \\
\text { Carr Index }(\%)\end{array}$ \\
\hline $\begin{array}{l}\text { Süt Tozu } \\
\text { Milk. Powder }\end{array}$ & $58.72 \pm 0.86^{a}$ & $1.50 \pm 0.01^{c}$ & $0.57 \pm 0.00^{\mathrm{b}}$ & $0.64 \pm 0.01^{b}$ & $11.01 \pm 0.01^{c}$ \\
\hline $\begin{array}{l}\text { Kazein } \\
\text { Casein }\end{array}$ & $2.87 \pm 0.38^{d}$ & $1.15 \pm 0.00^{d}$ & $0.60 \pm 0.00^{a}$ & $0.71 \pm 0.00^{a}$ & $16.00 \pm 0.00^{b}$ \\
\hline $\begin{array}{l}\text { Peynir Tozu } \\
\text { Cheese Powder }\end{array}$ & $42.62 \pm 2.68^{b}$ & $2.10 \pm 0.02^{\mathrm{b}}$ & $0.49 \pm 0.01^{\mathrm{d}}$ & $0.58 \pm 0.01^{c}$ & $16.00 \pm 0.01^{b}$ \\
\hline $\begin{array}{l}\text { Laktoz } \\
\text { Lactose }\end{array}$ & $30.13 \pm 3.84^{c}$ & $60.00 \pm 0.01^{\mathrm{a}}$ & $0.53 \pm 0.01^{c}$ & $0.68 \pm 0.01 \mathrm{a}, \mathrm{b}$ & $22.00 \pm 0.01^{a}$ \\
\hline
\end{tabular}

Yığın ve sıkıştırılmış yoğunluk toz endüstrisinde paketleme ve ambalaj materyali seçiminde ekonomik açıdan önem taşımaktadır. Ayrıca uzun süreli nakliye ve depolama özelliklerinin belirlenebilmesi için yığın yoğunluk analizi önemli bir değerlendirme kriteridir (Sharmavd., 2012). Toz süt ürünlerinin yığın yoğunluğu ekonomik, ticari ve işlevsel olarak önemli bir özelliktir. Bu bağlamda, toz ürünlerin özellikle uzun mesafelere taşınmas1 durumunda, paketleme hacmini azaltmak için yüksek bir yığın yoğunluğuna sahip olmaları önemlidir. Yüksek yığın yoğunluğu aynı zamanda ambalaj malzemesinden de tasarruf sağlar. Bir tozun yoğunluğu ayrıca kap hacmine, paketleme malzemelerinin gereksinimine ve prosesleme için makine seçiminde de göz önünde bulundurulmalıdır. Gıda ürünlerinde topaklaşma ya da kekleşmeye olan hassasiyetin bir göstergesi olduğundan düşük yığın yoğunluğu özellikle instant gida tozlarının dikkate alınması gereken önemli bir özelliğidir (Sharma vd., 2012). Yı̆̆ın ve sıkıştırılmış yoğunluk değerlendirmesi için yapılan hesaplamalar sonucunda her iki analiz için en düşük sonuçlar peynir tozunda, en yüksek sonuçlar ise kazeinde belirlenmiştir. Genel olarak, gida tozlarının ortalama yığın yoğunluğu değerleri 0.30 ile $0.80 \mathrm{~g} / \mathrm{cm}^{3}$ arasında, yağsız süt tozlarının ortalama yığın yoğunluğu değerleri ise 0.40 ile 0.45 $\mathrm{g} / \mathrm{cm}^{3}$ arasında değişmektedir (Kelly vd., 2002). Yığın yoğunluğu değerlerini etkileyen ana parametre tozların yapısı ve bileşimidir. Pürüzsüz ve tekdüze bir yapı yığın yoğunluğunu artırırken, toz yapıda tutunan havayı artıran gözeneklilik ise yığın yoğunluğunu azaltır (Kelly vd., 2002). Kurutma işlemi değişkenlerinin beyaz peynir tozu ürün kalitesine etkilerinin araştırldığı bir çalışma da peynir tozunun yığın yoğunluğu değeri $0.215-$ $0.261 \mathrm{~g} / \mathrm{cm}^{3}$ aralığında bulunmuş ve bu değerin literatürdeki değerlerden daha düşük olduğu ifade edilmiştir (Erbay vd., 2015). Aynı çalışmada literatüre göre elde edilen düşük yığın yoğunluğu değerinin temel nedenlerinden birinin peynir tozlarının yüksek yağ içeriklerinden kaynaklandığı belirtilmiştir. Yine doğal fosfokazeinat ile karışturılan laktozun yığın yoğunluğu değerinin ise $0.249 \mathrm{~g} / \mathrm{cm}^{3}$ olduğu rapor edilmiştir (Gaiani vd., 
2006). Ayrıca, Reddy vd. (2014)'nin püskürtmeli kurutucu kullanılarak toz haline getirilen keçi sütü tozlarının yığın yoğunluğu değerlerini $0.33-0.45$ $\mathrm{g} / \mathrm{cm}^{3}$ olarak belirlemiş ve proses koşullarının yığın yoğunluğunu etkilediğini vurgulamıştır. Öte yandan toz ürünlerin yoğunluk değerleri, proses ekipmanları seçimi için de önemli bir kriterdir ve düşük yığın yoğunluğu değerinin topaklaşmanın bir göstergesi olduğu ifade edilmektedir (BarbosaCánovas, 2005). Güçlü yapisal mukavemete sahip bir toz, bir taşıma sitemi içerisinde dağıldığında yığılmaya karşı direnç göstererek düşük bir yığın yoğunluğuna sahip olacakken, yapısal olarak zayıf bir toz kolayca çöküp yüksek yığın yoğunluğu sergileyecektir. Parçacıklar arasındaki yüksek sürtünme genellikler düşük bir yığın yoğunluğu ile sonuçlanır. Nitekim azalan sürtünme ile de ylğın yoğunluğu artar (Abdullah vd., 1999). Ayrıca yığın ve sıkışturlmış yoğunluk verileri ile hesaplanan ve akış davranışları hakkında bilgi veren Carr indeks değerlendirmesinde örneklerin farklı akış davranışları sergilediği görülmektedir. Toz ürünlerde Carr indeks değeri \%15'den küçükse çok iyi, \%15-20 aralığında ise iyi, \%20-35 orta, \%35-45 kötü ve \%45'den büyük değerlerde ise çok kötü akış tanımlaması yapılmaktadır (Santhalakshmy vd., 2015). Bu değerlendirmeye göre süt tozu çok iyi, kazein ve peynir tozu iyi, laktoz ise orta akış davranışı göstermektedir. Carr indeks sonuçları, çalışmamız kapsamında yapılan toz akış değerlendirmelerinden olan akış özelliği sonuçları ile paralellik göstermektedir.

\section{Toz akış özellikleri}

Toz gıda ürünlerinin sergilemiş oldukları toz akış özellikleri, toz ürünlerin raf ömrü süresince birbirine yapışma ve kekleşme eğiliminin bir göstergesi olması açısından önemlidir. Bu nedenle bu çalışmada ticari öneme sahip ve birçok gida ürününün formülasyonunda kullanılan toz süt ürünlerinin toz akış özellikleri belirlenerek birbirleri ile kıyaslanmıştır. Toz taneciklerinin birbirine tutunma ve daha büyük tanecik kümeleri oluşturma eğilimi kohezyon olarak tanımlanır. Toz süt ürünlerinin kohezyon indeksi değerleri ile bu değerlere karşılık gelen akış özellikleri, Benkovic and Bauman (2009)'1n kohezyon indeksi diğerine dayalı toz akış özelliklerini kategorize ettikleri ölçek ile belirlenerek Çizelge 3'te verilmiştir. En yüksek kohezyon indeksi değerine sahip laktoz, kohezif akış özelliği gösterirken; en düşük kohezyon indeksi değerine sahip süt tozu, serbest akış özelliği sergilemiştir. Peynir tozu ile kazein ise kolay akıs karakteristiği göstermiştir. Ayrıca, örneklerin kohezyon indeksi değerleri arasındaki farklılık istatistiksel $(P<0.05)$ olarak önemli bulunmuştur. Kohezyon indeksi değeri toz parçacıkların aglomerasyonu ve birbirine yapışma eğiliminin bir göstergesi olduğundan özellikle depolama ve paketleme aşamasında toz ürünlerin sergileyecekleri özelliklerin belirlenmesi açısından büyük öneme sahiptir (Oskaybaş, 2016). Toz süt ürünlerinin kohezyon indeksi değerleri ortalama tane boyutu ile ilişkilendirildiğinde ise nispeten küçük tanecik boyu dağılımına sahip ömeklerin kohezyon indeksi değerlerinin daha düşük olduğu gözlenmiştir. Elde edilen bu sonuç araştırmacıların geniş tanecik dağılımına sahip toz bileşenlerin dar tanecik dağılımına sahip toz sahip olanlara göre daha zor akış sergilediğini belirledikleri Altuntaş (2015)'in çalışması ile uyumludur. $\mathrm{Bu}$ durumun dişında toz süt ürünlerinin kohezyon özelliği higroskopisite, elektrostatik aktivite, gözeneklilik, tanecik boyutu ve şekli gibi çeşitli faktörlerden etkilendiğinin de belirtilmesi gerekir (Thomas vd., 2004).

PFSD testinde, sıkıştırma katsayıları her sıkıştırma döngüsünde kuvvet/mesafe eğrisinin altında kalan pozitif alandan hesaplanır (Göksel Saraç, 2018). PFSD testi ile akıs hızına bağlı olarak gıdaların akış davranış özellikleri ölçülür ve veriler toz gıda ürünlerinin işlenme, depolama ve taşınması sırasında sergileyeceği akış davranışları ile ilgili önemli bilgiler verir (Er vd., 2019). Artan test hızına bağlı olarak örneklerin gösterdikleri sıkışma katsayısı değerleri Şekil 2'de gösterilmiştir.

Şekilde de görüldüğ̈̈ üzere numunelerin sıkıştırma katsayısı değerlerinde en dikkat çekici farklılık peynir tozu örneğinde görülmüştür. Öte yandan, artan sıkıştırma katsayısı, toz bir ürünün yüksek taşıma hızlarında daha zor bir akış özelliği göstereceğini belirtir (Maja Benković vd., 2013). Toz ürünlerin akış özellikleri artan veya azalan akış hızı ile birlikte değişebilir. Örneğin, toz bir ürün hızlı akmaya zorlandıkça akışa daha dirençli 
hale gelebilir veya akış hızı arttıkça serbest akış özelliği gösterebilir (Doğan vd., 2019). Bu çalışmada ele alınan toz süt ürünlerinin sıkıştırma katsayısı değerleri, genellikle akış hızına bağlı olarak değişim göstermiştir. Kazein ve süt tozu örneklerinin sıkıştırma katsayısı değerlerinde artan test hızıyla azalma gözlenmiştir. Bu da kazein ve süt tozu örneklerinin yüksek akış hızlarında daha kolay aktı̆̆ının göstergesidir. Çizelge 4'te ticari öneme sahip toz süt ürünlerine ait PFSD testi sonuçlarına göre elde edilen akış stabilitesi değerleri $50 \mathrm{~mm} / \mathrm{s}$ 'deki kohezyon katsayıs değerleri verilmiştir. Toz süt ürünlerinin akış stabilitesi değerleri 0.91 ile 1.08 değerleri arasında gözlenmiştir. Örnekler arasındaki değişimin akıș stabilitesi değerleri üzerine etkisi ise istatistiksel olarak önemli bulunmuştur $(P<0.05)$. Akış stabilitesi 1.00 'e yakın olduğunda, toz ürünlerin analiz esnasında test hızının değişimi ile önemli ölçüde etkilenmediği belirtilmektedir (Benković vd., 2013). Ayrıca akış stabilitesi değeri toz bir ürünün akış direnci hakkında önemli ipuçlan verir. Akış stabilitesi değeri 1.00'den küçük veya büyük ise numunenin test esnasinda değişikliğe uğradığ1 sonucuna varılır. Gözlenen bu değişikliklerin nedeni de toz taneciklerinin aşınmasina veya aglomeraların parçalanmasına atfedilir (Doğan vd., 2019). $50 \mathrm{~mm} \mathrm{~s}^{-1}$ test hizinda toz süt ürünlerinin PFSD testi ile belirlenen kohezyon katsayısı değerleri -817.30 ile -1243.16 g.mm arasında değişmektedir. Elde edilen bu sonuçlar, Çizelge 3'te verilen kohezyon indeksi analizi sonuçları ile uyumludur.

Çizelge 3. Toz süt ürünlerinin kohezyon indeksi değerleri ve akış özellikleri Table 3. Cobesion index values and flow properties of powdered dairy products

\begin{tabular}{lcl}
\hline $\begin{array}{l}\text { Örnekler } \\
\text { Samples }\end{array}$ & $\begin{array}{c}\text { Kohezyon İndeksi } \\
\text { Cohesion Index }\end{array}$ & $\begin{array}{l}\text { Ak1ş Özelliği } \\
\text { Flow Behavior }\end{array}$ \\
\hline $\begin{array}{l}\text { Süt Tozu } \\
\text { Milk Powder }\end{array}$ & $9.59 \pm 0.16^{\mathrm{d}}$ & Serbest akış \\
Kazein & $13.41 \pm 0.08^{\mathrm{b}}$ & Kolay akış \\
$\begin{array}{l}\text { Casein } \\
\text { Peynir Tozu }\end{array}$ & $11.47 \pm 0.21^{\mathrm{c}}$ & Kolay akış \\
$\begin{array}{l}\text { Cheese Powder } \\
\text { Laktoz }\end{array}$ & $14.83 \pm 0.12^{\mathrm{a}}$ & Kohezif \\
Lactose & & \\
\hline
\end{tabular}

Aynı sütundaki farklı harfler örnekler arası farkın istatistiksel olarak önemli olduğunu gösterir. ortalama \pm standart sapma

Different letters on the same column indicate that the difference between the samples is statistically significant. mean土standard deviation

Çizelge 4. Toz süt ürünlerinin akış stabilitesi ve $50 \mathrm{~mm} / \mathrm{s}$ deki kohezyon katsayısı değerleri Table 4. Flow stability and cohesion coefficient values at $50 \mathrm{~mm} / \mathrm{s}$ of powdered milk. products

\begin{tabular}{|c|c|c|}
\hline $\begin{array}{l}\text { Örnekler } \\
\text { Samples }\end{array}$ & $\begin{array}{l}\text { Ak1ş Stabilitesi Değerleri } \\
\text { Flow Stability Values }\end{array}$ & $\begin{array}{c}\text { Kohezyon Katsayis1 (g.mm) } \\
\text { Cohesion Coefficient (g.mm) }\end{array}$ \\
\hline $\begin{array}{l}\text { Süt Tozu } \\
\text { Milk Powder }\end{array}$ & $1.00 \pm 0.02^{\mathrm{a}, \mathrm{b}}$ & $-817.30 \pm 12.91^{a}$ \\
\hline $\begin{array}{l}\text { Kazein } \\
\text { Casein }\end{array}$ & $1.08 \pm 0.09^{a}$ & $-1243.16 \pm 7.22^{\mathrm{d}}$ \\
\hline $\begin{array}{l}\text { Peynir Tozu } \\
\text { Cheese Powder }\end{array}$ & $0.91 \pm 0.03^{b}$ & $-883.99 \pm 15.70^{b}$ \\
\hline $\begin{array}{l}\text { Laktoz } \\
\text { Lactose }\end{array}$ & $1.00 \pm 0.03^{\mathrm{a}, \mathrm{b}}$ & $-1156.75 \pm 14.59 c$ \\
\hline
\end{tabular}

Aynı sütundaki farklı harfler örnekler arası farkın istatistiksel olarak önemli olduğunu gösterir. ortalama \pm standart sapma

Different letters on the same column indicate that the difference between the samples is statistically significant. mean土standard deviation 


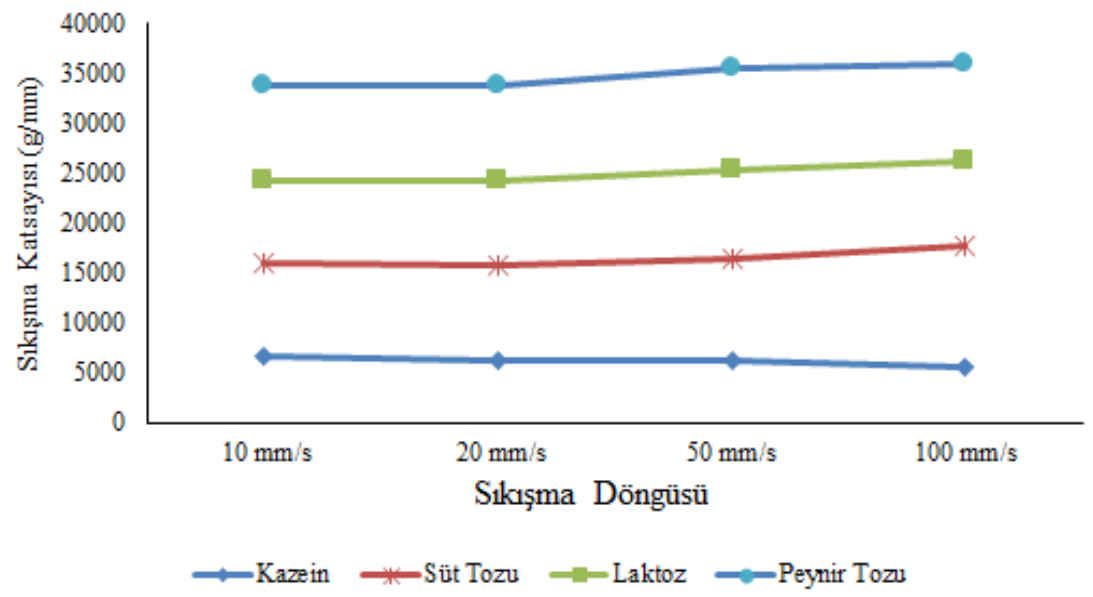

Şekil 2. PFSD testinde artan test hızlanına bağlı olarak örneklerin sıkışma katsayısı değerleri

Figure 2. The compression coefficient values of the samples depending on the increasing test speeds in the PFSD test

Düşük nem içeriğine sahip amorf toz gida ürünlerinde gözlenen kekleşme, tozların önce topaklara, ardından topak halinde yapışkan istenmeyen bir malzemeye dönüştügü, toz ürünün kalite ve işlevselliğinin azalmasına neden olan zararlı bir oluşumdur (Aguilera vd., 1995). Toz gıda ürünlerinde görülen kekleşme sonucu oluşan ürünler, küçük ve dağılabilir özellikteki oluşumlardan ürünün akışkanlığın kaybına neden olan sert topakların olușumuna kadar farklı özellikler sergileyebilir (Mercan vd., 2018). Süt tozlarının kekleşme özellikleri ve kekleşmeye olan duyarlllığını belirlenmesi de ürünlerin işleme, depolama ve taşıma özellikleri hakkında önemli bilgiler verebilir. Şekil 3'te örneklerin her bir döngüde gösterdikleri kekleşme yükseklik oranı değerleri verilmiştir.

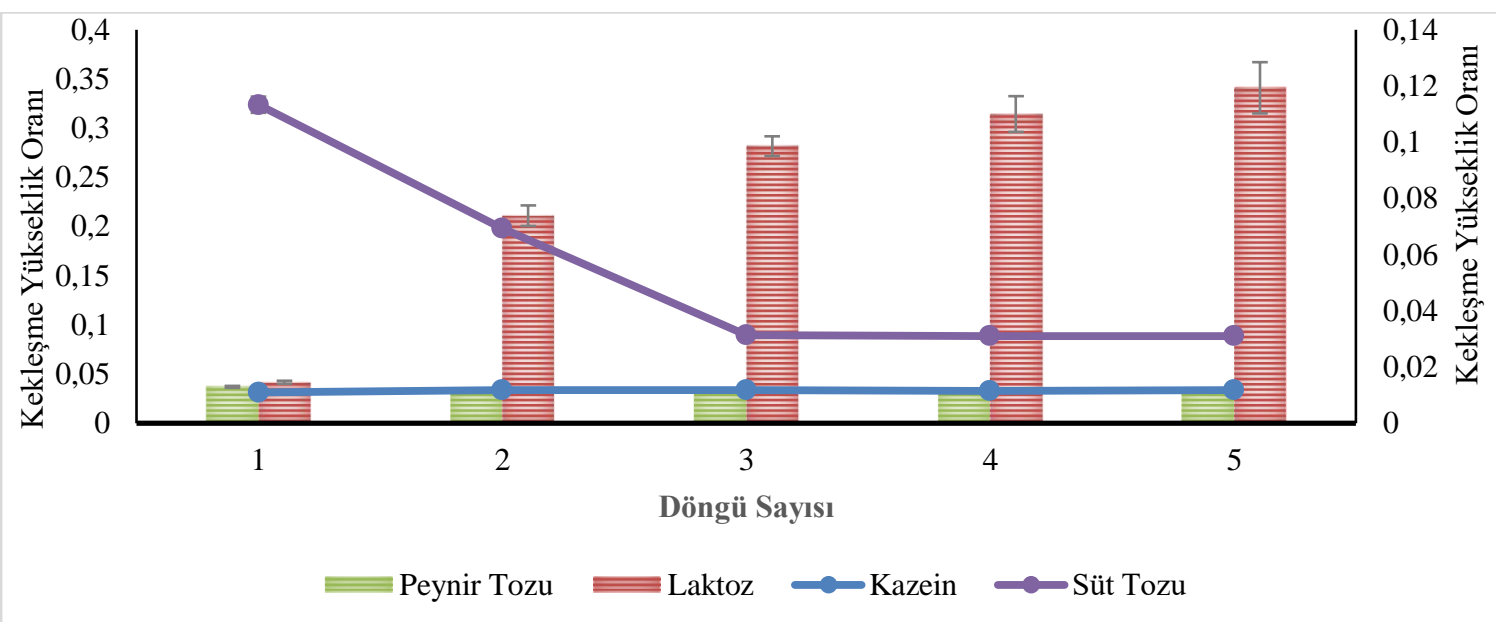

Şekil 3. Örneklerin her bir döngüde gösterdikleri kekleşme yükseklik oranı değerleri

Figure 3. The cake height ratio values shown by the samples in each cycle

Döngü sayısına bağlı olarak peynir tozu ve kazein tozlanının kekleşme yükseklik oranında kayda değer bir değişimin olmadığını göstermiştir. Şekil 3 incelendiğinde 1 ve 5 . döngüler arasında görülen en belirgin değişim laktoz ve süt tozunda kaydedilmiştir. Laktoza ait kekleşme yükseklik oranı değerleri incelendiğinde artan döngü sayısı ile birlikte kekleşme yükseklik oranında arttığı gözlenmiştir. Kekleşme yükseklik oranında görülen keskin artş, toz örneğinin, kek 
oluşumuna oldukça eğilimli olduğunu göstermektedir (Benković vd., 2017). Ayrica, Çizelge 5'te verilen toz süt ürünlerinin kekleşme ve ortalama kekleşme kuvveti değerleri ile Şekil 3'te elde edilen verilerin birbirleri ile uyumlu olduğu gözlenmektedir. Nitekim incelenen toz gıda ürünleri içerisinde artan döngü sayısı ile birlikte kekleşme yükseklik oranının da arttığı tek örnek olan laktozda kekleşme kaydedilirken peynir tozu, süt tozu ve kazeinde kekleşme meydana gelmemiştir.

Çizelge 5. Toz süt ürünlerinin kekleşme ve ortalama kekleşme kuvveti değerleri

Table 5. Cake strength and mean cake strength values of powdered dairy products

\begin{tabular}{lcc}
\hline $\begin{array}{l}\text { Örnekler } \\
\text { Samples }\end{array}$ & $\begin{array}{c}\text { Kekleşme Kuvveti }(\mathrm{g} . \mathrm{mm}) \\
\text { Cake Strength }(g . m m)\end{array}$ & $\begin{array}{c}\text { Ortalama Kekleşme Kuvveti }(\mathrm{g}) \\
\text { Mean Cake Strength }(g)\end{array}$ \\
\hline $\begin{array}{l}\text { Süt Tozu } \\
\text { Milk Powder }\end{array}$ & Kekleşme oluşmadı & Kekleşme oluşmadı \\
$\begin{array}{l}\text { Kazein } \\
\text { Casein }\end{array}$ & Kekleşme oluşmadı & Kekleşme oluşmadı \\
$\begin{array}{l}\text { Peynir Tozu } \\
\text { Cheese Powder }\end{array}$ & Kekleşme oluşmadı & Kekleşme oluşmadı \\
Laktoz & $941.69 \pm 8.15$ & $56.64 \pm 2.43$ \\
Lactose & & \\
\hline
\end{tabular}

\section{Elek analizi}

Toz süt ürünlerinin elek analizi sonuçlarına göre elek numaralanna bağlı yüzde birikme miktarlarının ve ortalama elek boyutları Şekil 4'de gösterilmektedir. Kazein $144.4 \mu \mathrm{m}$ değeri ile en yüksek tanecik boyutuna sahip ürün olarak belirlenirken, süt tozu ortalama tanecik boyutu en düșük $(82.5 \mu \mathrm{m})$ ürün olarak belirlenmiștir. Elde edilen sonuçlar, süt tozlarının bileșiminde görülen farklılıkların süt tozlarının bazı fizikokimyasal özellikleri üzerine etkisinin incelendiği Tuohy (1989) 'nın çalışması ile kıyaslanabilir. Tuohy (1989) çalışmalarında düzenli bir yapıya sahip yağsız süt tozlarının ortalama tanecik boyutunun $85 \mu \mathrm{m}$, tam yağlı süt tozlarında ise 230 ile $250 \mu \mathrm{m}$ arasında değiştiğini rapor etmiştir.

Tanecik boyutu, toz ürünlerde toz akış başta olmak üzere birçok ürün özelliğini ve depolama sürecinde ürünlerde meydana gelen değişimleri etkilemektedir. Tanecik büyüklüğü azalmasının akış davranış indeksini azalttığı kaydedilmiştir (Yu vd., 2018). Benzer şekilde en düşük ortalama tanecik boyutuna sahip süt tozunun, örnekler içerisinde en düşük kohezyon indeksine sahip olduğu belirlenmiştir. Ayrıca Thomas vd. (2004) tanecik boyutunun süt tozlarında kohezyonu etkilediği, Sharmavd. (2012) ise yığın yoğunluğunu etkileyen parametreler içerisinde olduğunu ifade etmektedir. Benzer șekilde yapılan bașka bir çalışmada parçacık boyutu değişiminin tozlanın akışkanlığını ve özelliklerini etkilediği belirlenmiştir (Doğan vd., 2019).

\section{Morfolojik yapı analizi}

Toz süt ürünlerinin mikro yapıları 250x ve 2000x büyütme ile Șekil 5'de gösterilmiștir. Örnekler arasında kazein ve laktozun șekil benzerliği kısmen bulunsa da tanecik büyüklüğü açısından incelendiğinde laktozun daha küçük yapıda olduğu görülmektedir. Her iki örnekte düzenli bir şekil yapısı gözlenmemiş, laktozun yüzey yapısının daha pürüzlü olduğu belirlenmiştir. Öte yandan peynir tozunda oldukça farklı yüzey karakteristiği tespit edilmiştir. Bu durumun üretim ve öğütme sürecinde uygulanan proses parametreleri ile ilgili olduğunu düşünülmektedir. Süt tozu örneğinde ise diğer toz süt ürünlerine göre daha düzgün dairesel yapılar belirlenmiştir. Pürüzlü yapıda bulunan kazein ve laktozun en yüksek, süt tozunun ise en düşük kohezyon indeksine sahip olduğu belirlenmiştir. Öte yandan en pürüzlü yüzeye sahip laktoz örneği kohezif akış, en yuvarlak ve pürüzsüz yapıya sahip süt tozu örneğinin ise serbest ak1ş gösterdiği toz akış sonuçları ve SEM görüntüleri yorumlandığında görülmektedir. Laktoz için morfoloji değerlendirmelerinde iki farklı yap1 
gözlenmektedir. Bunlardan ilki kavisli iğne benzeri yapıdır ve $\beta$-laktoz karakteristiğini ifade eder, diğer şekil ise savaş baltası (tomahawk) şeklidir ve $\alpha$-laktozdan oluşan formlarda gözlenir (Lara-Mota vd., 2020). Bu kapsamda çalışmada kullanilan laktoz $\alpha$-laktoz karakteristiği göstermektedir. Kazein ise herhangi bir işlem uygulanmadığında kompakt yapıda gözlenmektedir ve kazein SEM görüntüleri literatür çalışmaları ile benzerlik göstermektedir (Xu vd., 2020). Toz ömekleri yüksek yağ içeriğine sahip olduklarında küresel ve pürüzlü parçacık yapıları göstermektedir (da Silva vd., 2018; Pierre Schuck, 2009). Süt tozu ve peynir tozunda yă̆ oranı artışına bağlı olarak yuvarlak ve pürüzlü yüzeyler tespit edilmiştir.
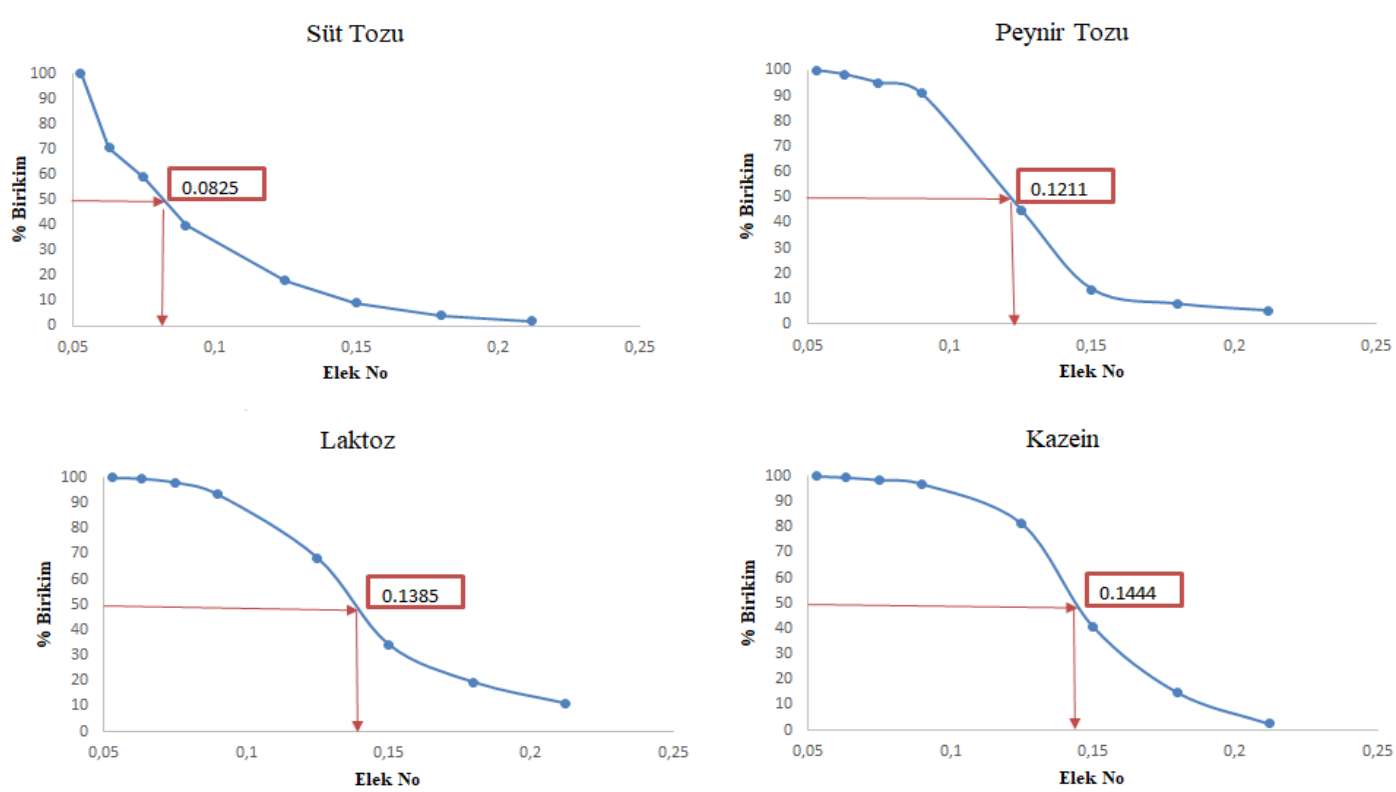

Şekil 4. Toz süt ürünlerinin ortalama tane boyutu Figure 4. Average particle size of powdered dairy products

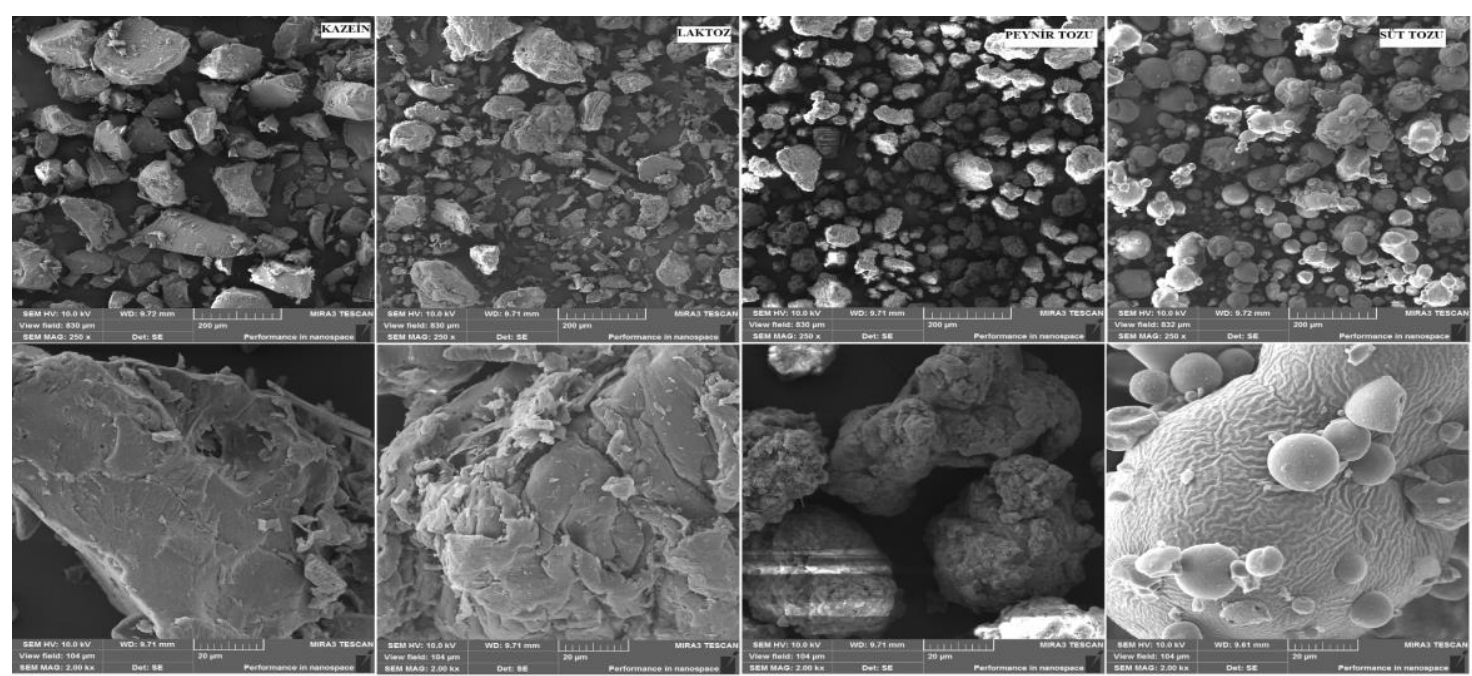

Şekil 5. Toz süt ürünlerinin SEM görüntüleri

Figure 5. SEM images of powdered dairy products 


\section{SONUÇ}

Toz süt ürünleri özellikle tüketime hazır ve kolay hazırlanan (instant) toz ürünler içerisinde besinsel değeri artırmak, aroma ve tat geliştirmek, dolgu malzemesi olmak, kıvam vermek gibi özellikleri nedeniyle oldukça yüksek oranlarda kullanılmaktadır. Toz ürünler, uzun depolama süresi olan ve kolay bozulmayan ürünler olarak bilinmektedir. Uzun depolama süresinde ürün yapisinda meydana gelecek topaklanmalar sorun oluşturabilmektedir. Öte yandan süt ve ürünlerinden elde edilen tozların formülasyonuna katıldığ1 ürünlerin ambalaj materyali ve üretim hattında kullanılacak makine ve ekipman seçiminde önemli etkilerinin olduğu bilinmektedir. $\mathrm{Bu}$ nedenle çalışma kapsamında değerlendirilen toz süt ürünlerinin fizikokimyasal, toz ve toz akış özelliklerinin birbirini etkilediği belirlenmiştir. Ticari öneme sahip toz süt ürünlerinin ortalama tanecik boyutu ile çözünürlük değerleri değerlendirildiğinde en düşük tanecik boyutuna sahip örneğin süt tozu olduğu ve yine süt tozu örneğinin en yüksek çözünürlüğe (\%58.72) sahip örnek olduğu görülmüştür. Toz süt ürünlerinin çözünürlük ve tanecik boyutu arasındaki ilişki birlikte incelendiğinde ise daha büyük ortalama tanecik boyutuna sahip örneklerin çözünürlük değerlerinin daha düşük olduğu sonucuna varılmıştır. Bunun nedeni, tanecik boyutunun materyallerin çözünme davranışını etkilemesidir (Sun vd., 2012). Parçackk boyutundaki azalma, difüzyon mesafesini azaltarak çözünme oranını artırabilmektedir. Boyut olarak daha büyük tanecik boyutuna sahip materyaller göreceli olarak dar bir yüzey alanına sahip olduğundan çözünme oranları daha düşüktür (Sharma vd., 2015). Çalışma sonuçlarına paralel olarak tanecik boyutundaki azalma ile çözünürlük değerlerinin artmasının nedeninin azalan yüzey alanıyla birlikte difüzyon mesafesinin azalması ve böylece örneklerin çözünme oranının arttı̆̆1 sonucuna varılmıştır. Öte yandan Carr indeks ile kohesyon indeksi sonuçlarının paralellik gösterdiği tespit edilmiştir. Toz akış değerlendirmelerinden olan kekleşme kuvveti verileri incelendiğinde kekleşme oluşan tek ürün laktoz olarak belirlenmiştir. Ayrıca ürünlerin renk değerleri incelendiğinde, örneklerin birbirinden oldukça farklı değerlere sahip olduğu tespit edilmiştir. $\mathrm{Bu}$ durum ise formülasyonuna ilave edildikleri ürünlerde istenen renk aralığının belirlenmesi için düzenlemeler yapılmas1 gerekliliğini göstermektedir. Toz ürünlerin özellikleri ürün formülasyonu hazırlaması ve depolaması için önemlidir. $\mathrm{Bu}$ nedenle bu çalışma yaptığı karakterizasyon ve ilişkilendirme çalışmaları ile literatür için değerli görülmektedir. Bu aşamadan sonra ürün grupları kendi içlerinde seçilerek farklı ürünlerle etkileşimleri toz akış özellikleri açısından gözlenebilir. Ayrıca ürünlerin üretim aşamasından itibaren depolama sürecinde meydana getirdiği değişimler izlenebilir. Toz ürünleri işleme ve özelliklerini belirleme, karmaşık yapıları ve toz ürün formülasyonunda bulunan diğer ürünler nedeniyle önemlidir ve bu konu üzerinde yeni çalışmalar planlanabilir.

\section{ÇIKAR ÇATIŞMASI BEYANI}

Yazarlar, bu makale ile ilgili başka kişi veya kurumlar ile çıkar çatışması olmadığını beyan etmektedir.

\section{YAZAR KATKILARI}

Makalenin fikir/kavram ve denetleme/danışmanlık ile makalenin genel düzeni aşamasına katkı yapan yazar Mahmut Doğan'dır. Veri toplama, tasarım, yöntem, analiz verilerin işlenmesi kaynak taraması ve yorum aşamasında katkı yapan yazarlar, Meryem GökselSaraç ve Duygu Aslan-Türker'dir. Yazarlar makalenin son halini okumuş ve onaylamıştır.

\section{KAYNAKLAR}

Abdullah, E. C., Geldart, D. (1999). The use of bulk density measurements as flowability indicators. Powder Techn, 102(2), 151-165. doi: https://doi.org/10.1016/S0032-5910(98)002083

Aguilera, J., del Valle, J.,Karel, M. (1995). Caking phenomena in amorphous food powders.. Trends Food Sci. Technol., 6(5), 149-155. doi: 10.1016/S0924-2244(00)89023-8

Altuntaş, F. (2015). Prebiyotik Hažr Etsiz Toz Ciğ Köfte Üretimi. Yüksek Lisans Tezi, Erciyes Üniversitesi, Kayseri. 
AOAC. (2000). Official Methods of Analysis of AOAC International. Association of Official Analysis Chemists International. Washington DC, the USA.

Barbosa-Cánovas, G. V. (2005). Physical and chemical properties of food powders. Encaps. and Powder. Foods, 39-71.

Benkovic, M., Bauman, I. (2009). Flow properties of commercial infant formula powders. World Acad Sci Eng Technol, 54(6), 495-499.

Benković, M., Belščak-Cvitanović, A., Bauman, I., Komes, D.,Srečec, S. (2017). Flow properties and chemical composition of carob (Ceratonia siliqua L.) flours as related to particle size and seed presence. Food Res. Int., 100, 211-218. doi: 10.1016/j.foodres.2017.08.048

Benković, M., Belščak-Cvitanović, A., Komes, D., Bauman, I. (2013). Physical Properties of NonAgglomerated Cocoa Drink Powder Mixtures Containing Various Types of Sugar and Sweetener. Food Bioproc Tech, 6(4), 1044-1058. doi: 10.1007/s11947-011-0742-0

Benković, M., Srečec, S., Špoljarić, I., Mršić, G., Bauman, I. (2013). Flow Properties of Commonly Used Food Powders and Their Mixtures. Food Bioproc Tech, 6(9), 2525-2537. doi: 10.1007/s11947-012-0925-3

Börjesson, E., Innings, F., Trägårdh, C., Bergenståhl, B., Paulsson, M. (2013). The dissolution behavior of individual powder particles. Dairy Sci Technol, 93(4-5), 357-371.

Carić, M. (1994). Concentrated and dried dairy products: VCH Publishers Inc.

Carpin, M., Bertelsen, H., Bech, J. K., Jeantet, R., Risbo, J., Schuck, P. (2016). Caking of lactose: A critical review. Trends Food Sci. Technol., 53, 1-12. doi: https://doi.org/10.1016/j.tifs.2016.04.002

Chudy, S., Pikul, J., Rudzińska, M. (2015). Effects of storage on lipid oxidation in milk and egg mixed powder.

da Silva, D. F., Hirschberg, C., Ahrné, L., Hougaard, A. B., Ipsen, R. (2018). Cheese feed to powder: Effects of cheese age, added dairy ingredients and spray drying temperature on properties of cheese powders. J. Food Eng., 237, 215-225.

de Freitas Eduardo, M., da Silva Lannes, S. C. (2007). Use of texture analysis to determine compaction force of powders. J. Food Eng., 80(2), 568-572.

Doğan, M., Aslan, D., Gürmeriç, V., Özgür, A.,Göksel Saraç, M. (2019). Powder caking and cohesion behaviours of coffee powders as affected by roasting and particle sizes: Principal component analyses (PCA) for flow and bioactive properties. Powder Techn, 344, 222-232. doi: https://doi.org/10.1016/j.powtec.2018.12.030

Du, S.-k., Jiang, H., Yu, X.,Jane, J.-l. (2014). Physicochemical and functional properties of whole legume flour. LWT-Food Sci Technol., 55(1), 308-313.

Er, B., Sert, D., Mercan, E. (2019). Production of skim milk powder by spray-drying from transglutaminase treated milk concentrates: Effects on physicochemical, powder flow, thermal and microstructural characteristics. Int. Dairy J., 99, 104544. doi: https://doi.org/10.1016/j.idairyj.2019.104544

Erbay, Z., Koca, N., Kaymak-Ertekin, F.,Ucuncu, M. (2015). Optimization of spray drying process in cheese powder production. Food Bioprod Process, 93, 156-165. doi: https://doi.org/10.1016/ j.fbp.2013.12.008

Fäldt, P., Bergenståhl, B. (1996). Spray-dried whey protein/lactose/soybean oil emulsions. 2 . Redispersability, wettability and particle structure. Food Hydrocoll, 10(4), 431-439.

Fitzpatrick, J. J., Barry, K., Cerqueira, P. S. M., Iqbal, T., O’Neill, J., Roos, Y. H. (2007). Effect of composition and storage conditions on the flowability of dairy powders. Int. Dairy J., 17(4), 383-392. doi: https://doi.org/10.1016/j.idairyj. 2006.04.010

Fitzpatrick, J. J., O'Connor, J., Cudmore, M., Dos Santos, D. (2017). Caking behaviour of food powder binary mixes containing sticky and nonsticky powders. J. Food Eng., 204, 73-79. doi: https://doi.org/10.1016/j.jfoodeng.2017.02.021 
Forny, L., Marabi, A., Palzer, S. (2011). Wetting, disintegration and dissolution of agglomerated water soluble powders. Powder Techn, 206(1-2), 7278.

Freudig, B., Hogekamp, S., Schubert, H. (1999). Dispersion of powders in liquids in a stirred vessel. Chem Eng Process, 38(4-6), 525-532.

Gaiani, C., Ehrhardt, J. J., Scher, J., Hardy, J., Desobry, S.,Banon, S. (2006). Surface composition of dairy powders observed by X-ray photoelectron spectroscopy and effects on their rehydration properties. Colloids Surf. B, 49(1), 7178. doi: https://doi.org/10.1016/j.colsurfb.2006.02.015

Göksel Saraç, M. (2018). Rendering Artık Yağlarından Emülgatör Üretimi ve Model G1dalarda Arayüzey (interfacial) Reolojik Uygulamaları. Erciyes Üniversitesi, Fen Bilimleri Enstitüsü Gida Mühendisliği Anabilim Dalı Doktora Tezi, Kayseri,Türkiye.

Himmetağaoğlu, A. B., Erbay, Z., Çam, M. (2019). Süt Yağının Toza Dönüş̧ürülmesi ve Krema Tozu. Academic Food J., 17(1).

IDF, I. D. F. (2012). The World Dairy Situation 2012. Bulletin of the International Dairy Federation (Vol. 458/2012.). Brussels, Belgium.

Jeantet, R., Schuck, P., Six, T., Andre, C., Delaplace, G. (2010). The influence of stirring speed, temperature and solid concentration on the rehydration time of micellar casein powder. Dairy Sci Technol, 90(2-3), 225-236.

Kelly, J., Kelly, P. M., Harrington, D. (2002). Influence of processing variables on the physicochemical properties of spray dried fatbased milk powders. Le Lait, 82(4), 401-412.

Kim, E. H. J., Chen, X. D., Pearce, D. (2002). Surface characterization of four industrial spraydried dairy powders in relation to chemical composition, structure and wetting property. Colloids Surf. B, 26(3), 197-212. doi: https://doi.org/10.1016/S0927-7765(01)003344

Landillon, V., Cassan, D., Morel, M.-H., Cuq, B. (2008). Flowability, cohesive, and granulation properties of wheat powders. J. Food Eng., 86(2), 178-193.

Lara-Mota, E. E., Nicolás-Vázquez, M. I., LópezMartínez, L. A., Espinosa-Solis, V., CruzAlcantar, P., Toxqui-Teran, A., Saavedra-Leos, M. Z. (2020). Phenomenological study of the synthesis of pure anhydrous $\beta$-lactose in alcoholic solution. Food Chem, 128054.

Mathlouthi, M., Rogé, B. (2003). Water vapour sorption isotherms and the caking of food powders. Food Chem, 82(1), 61-71. doi: 10.1016/S0308-8146(02)00534-4

Mercan, E., Sert, D., Akin, N. (2018). Determination of powder flow properties of skim milk powder produced from high-pressure homogenization treated milk concentrates during storage. LWT-Food Sci Technol, 97, 279-288. doi: https://doi.org/10.1016/j.lwt.2018.07.002

O'Donoghue, L. T., Haque, M. K., Kennedy, D., Laffir, F. R., Hogan, S. A., O'Mahony, J. A., Murphy, E. G. (2019). Influence of particle size on the physicochemical properties and stickiness of dairy powders. Int. Dairy J., 98, 54-63. doi: ttps://doi.org/10.1016/j.idairyj.2019.07.002

Oskaybaş, B. (2016). Çerezlik Kabak Posası Kullanilarak Diyet Lifi ve Pektin Üretimi. Erciyes Üniversitesi, Fen Bilimleri Enstitüsü G1da Mühendisliği Anabilim Dalı Yüksek Lisans Tezi, Kayseri,Türkiye.

Özcan, D. (2011). Süt ve Süt Ürünlerinde Tüketici Talebi ve Satın Alma Karanna Etki Eden Faktörler Üzerine Bir Araştırma: İzmir İli Örneği. Ege Üniversitesi Fen Bilimleri Enstitüsü Yüksek Lisans Tezi, Bornova, İzmir.

Provent, B., Chulia, D., Cary, J. (1993). Particle size and the caking tendency of a powder. Eur J Pharm Biopharm 39(5), 202-207.

Reddy, R. S., Ramachandra, C. T., Hiregoudar, S., Nidoni, U., Ram, J., Kammar, M. (2014). Influence of processing conditions on functional and reconstitution properties of milk powder made from Osmanabadi goat milk by spray drying. Small Rumin. Res, 119(1), 130-137. doi: https://doi.org/10.1016/j.smallrumres.2014.01. 013 
Santhalakshmy, S., Bosco, S. J. D., Francis, S., Sabeena, M. (2015). Effect of inlet temperature on physicochemical properties of spray-dried jamun fruit juice powder. Powder Techn, 274, 37-43.

Schubert, H. (1993). Instantization of powdered food products. Int. Chem. Eng, 33(1), 28-45.

Schuck, P. (2009). Understanding the factors affecting spray-dried dairy powder properties and behavior Dairy-derived ingredients (pp. 24-50): Elsevier.

Schuck, P. (2011). Milk Powder: Types and Manufacture. Encyclopedia of Dairy Science, 108-117.

Schuck, P., Jeantet, R., Dolivet, A. (2012). Analytical methods for food and dairy powders: John Wiley \& Sons.

Sharma, A., Jana, A. H., Chavan, R. S. (2012). Functionality of milk powders and milk-based powders for end use applications - a review. Compr. Rev. Food Sci. Food Saf., 11(5), 518-528.

Sharma, S., Verma, A., Teja, B. V., Shukla, P., Mishra, P. R. (2015). Development of stabilized Paclitaxel nanocrystals: In-vitro and in-vivo efficacy studies. Eur J Pharm Sci, 69, 51-60. doi: https://doi.org/10.1016/j.ejps.2014.11.012

Sun, J., Wang, F., Sui, Y., She, Z., Zhai, W., Wang, C., Deng, Y. (2012). Effect of particle size on solubility, dissolution rate, and oral bioavailability: Evaluation using coenzyme Q10 as naked nanocrystals. Int J Nanomedicine, 7, 5733.

Takahashi, S., Seib, P. (1988). Paste and gel properties of prime corn and wheat starches with and without native lipids. Cereal Chem, 65(6), 474483.
Tamime, A. (2009). Dried milk products. Dairy powders and concentrated milk products: Oxford, UK: Blackwell Pub. Ltd.

Thomas, M. E., Scher, J., Desobry-Banon, S., Desobry, S. (2004). Milk powders ageing: effect on physical and functional properties. Crit Rev Food Sci Nutr, 44(5), 297-322.

Troy, H. C., Sharp, P. F. (1930). $\alpha$ and $\beta$ Lactose in Some Milk Products. J Dairy Sci, 13(2), 140-157. doi: 10.3168/jds.S0022-0302(30)93513-8

Tuohy, J. (1989). Some physical properties of milk powders. Irish J Agr Food Res, 141-152.

Turchiuli, C., Fuchs, M., Bohin, M., Cuvelier, M.E., Ordonnaud, C., Peyrat-Maillard, M., Dumoulin, E. (2005). Oil encapsulation by spray drying and fluidised bed agglomeration. Innov Food Sci Emerg Technol., 6(1), 29-35.

Xu, B., Yuan, J., Wang, L., Lu, F., Wei, B., Azam, R. S., Ren, X., Zhou, C., Ma, H., Bhandari, B. (2020). Effect of multi-frequency power ultrasound (MFPU) treatment on enzyme hydrolysis of casein. Ultrason Sonochem, 63, 104930.

Yu, Z.-Y., Jiang, S.-W., Cai, J., Cao, X.-M., Zheng, Z., Jiang, S.-T., Wang,H-L., Pan, L.-J. (2018). Effect of high pressure homogenization (HPH) on the rheological properties of taro (Colocasia esculenta (L). Schott) pulp. Innov Food Sci Emerg Technol., 50, 160-168.

Zafar, U., Vivacqua, V., Calvert, G., Ghadiri, M.,Cleaver, J. A. S. (2017). A review of bulk powder caking. Powder Techn, 313, 389-401. doi: https://doi.org/10.1016/j.powtec.2017.02.024 